\title{
PENGARUH KONSERVATISME TERHADAP ASIMETRI INFORMASI (Studi Empiris pada Perusahaan Manufaktur di BEI)
}

\author{
Aida Yulia \\ Tommy Harvi
}

\begin{abstract}
The purpose of this study was to determine the effect of accounting conservatism on information asymmetry in the annual reports of companies listed on the Indonesia Stock Exchange.

Target population in this study is a manufacturing company listed on the Indonesia Stock Exchange (BEI) with year observations from 2009 to 2011 the number of companies by 23 companies.

Of accounting conservatism measurements conducted on 23 companies, the population of the obtained results of all companies that meet more than one measurement assumptions of accounting conservatism with market value to book value ratio greater than 1 , so that the company can be classified as a conservative company. From the test results it can be concluded that the regression coefficient of determinant (R2) value 0.240 indicates that accounting conservatism is able to affect the asymmetry of information in the annual reports of companies listed on the Indonesia Stock Exchange amounted to 24.0 percent and the remaining 76.0 percent is influenced by other variables outside of the research model. Piecemeal evidence suggests that accounting conservatism variable regression coefficient of $-0.474,(\beta \neq 0)$, meaning that in partial accounting conservatism and significant negative effect of the information asymmetry in the annual reports of companies listed on the Indonesia Stock Exchange. Refers to the requirement that the results of the study reject $\mathrm{Ho}$ and accept $\mathrm{Ha}$.
\end{abstract}

Keywords: Accounting Conservatism and Information Asymmetry 


\section{Pendahuluan}

Laporan keuangan merupakan bentuk pertanggungjawaban manajemen kepada pihak investor dalam mengelola sumber daya perusahaan yang telah dipercayakan kepadanya. Laporan keuangan harus dibuat berdasarkan Standar Akuntansi Keuangan (SAK) yang telah disusun oleh Dewan Standar Akuntansi Keuangan (DSAK). Laporan keuangan yang disajikan harus bermanfaat bagi pengguna dalam pengambilan keputusan. Banyak pihak yang berkepentingan membutuhkan informasi keuangan antara lain, investor, karyawan, pemberi pinjaman, pelanggan, pemerintah, dan masyarakat.

Dalam penyusunan laporan keuangan, manajemen perusahaan sebagai agent lebih mengetahui tentang kondisi keuangan secara keseluruhan dibandingkan pihak principal (pemilik). Hal inilah yang mendasari timbulnya asimetri informasi, dimana pihak manajemen lebih mengetahui kondisi perusahaaan secara keseluruhan dibandingkan pihak principal.

Asimetri informasi merupakan fenomena yang masih sangat sering terjadi di lingkungan bisnis saat ini. Kasus yang cukup mengejutkan beberapa tahun terakhir ialah kasus manipulasi laporan keuangan yang dilakukan oleh Enron dengan melaporkan laporan keuangan yang overstated (berlebihan). Salah satu kasus manipulasi laporan keuangan yang ada di Indonesia terungkap pada bulan November 2010 lalu dimana PT. Kimia Farma terlibat skandal penyajian aktiva yang overstated.

Asimetri informasi merupakan kondisi dimana pihak manajemen memiliki informasi lebih banyak dibandingkan dengan pihak investor. Asimetri informasi merupakan salah satu faktor yang dapat menyebabkan manipulasi laporan keuangan. Selain itu penilaian kerja manajemen dan pemberian bonus juga merupakan faktor pendukung manipulasi laporan keuangan. Manipulasi yang paling sering dilakukan adalah overstated laba. Hal ini disebabkan karena laba dapat mencerminkan kinerja operasional perusahaan dan menjadi perhatian pengguna laporan keuangan dalam menilai perusahaan. Selain itu kinerja operasional perusahaan juga berpengaruh terhadap harga saham perusahaan. Kesempatan untuk memilih beberapa metode akuntansi membuka peluang bagi manajer melakukan manipulasi laporan keuangan. Oleh karena itu, salah satu cara yang dapat dilakukan untuk mencegah manipulasi laporan keuangan adalah dengan memilih prinsip akuntansi konservatif (Haniati dan Fitriany, 2010).

Konservatisme akuntansi
merupakan prinsip yang menganut kehatihatian dalam menghadapi ketidakpastian. Givoly dan Hayn (2006) mengartikan konservatisme sebagai prinsip yang mempercepat pengakuan biaya dan rugi serta menunda pengakuan pendapatan dan keuntungan, sehingga laporan keuangan yang akan dihasilkan dari prinsip konservatisme merupakan laporan keuangan yang understated (tidak berlebihan).

Manipulasi laporan keuangan merupakan penyebab adanya asimetri informasi. Manipulasi laporan keuangan yang paling sering dilakukan adalah dalam bentuk overstated laba. Laba merupakan informasi penting mengenai gambaran kinerja perusahaan dan menjadi perhatian para pengguna laporan keuangan dalam menilai perusahaan (Haniati dan Fitriany, 2010).

Watts (2003) sebagai pendukung konservatisme berpendapat bahwa konservatisme merupakan salah satu karakteristik yang sangat penting dalam mengurangi biaya agensi dan meningkatkan kualitas informasi laporan keuangan sehingga pada akhirnya akan meningkatkan nilai perusahaan dan harga sahamnya. Para pemegang saham mempunyai harapan agar manajemen bertindak atas kepentingan mereka. Untuk itu dibutuhkan pengawasan seperti pemeriksaan laporan keuangan serta pembatasan keputusan yang dapat diambil manajemen. Biaya yang dikeluarkan untuk kegiatan pengawasan tersebut disebut sebagai biaya agensi.

Pendapat lainnya, Ahmed et al. (2002) sebagai pendukung konservatisme berpendapat bahwa konservatisme dapat mengurangi konflik antara bondholdersshareholders (pemegang obligasipemegang saham) seputar kebijakan deviden. Pembayaran deviden yang terlalu tinggi akan menimbulkan ancaman bagi debt holders (pemegang hutang) karena akan mengurangi aktiva yang seharusnya tersedia untuk pelunasan utang. Mengatasi masalah ini, tindakan yang biasa dilakukan adalah dengan melakukan pembatasan pembagian deviden berdasarkan perolehan laba perusahaan. Untuk itu dibutuhkan penyajian laba yang konservatif demi 
membatasi pembayaran deviden yang terlalu tinggi serta penyajian aktiva yang konservatif untuk memberikan gambaran kepada debtholders (pemegang hutang) tentang ketersediaan aktiva untuk pembayaran hutang.

Banyak pihak yang mendukung dan menolak konsep konservatisme, karena bagi mereka laporan keuangan yang disajikan dengan menggunakan prinsip konservatisme akan mengakibatkan laporan keuangan menjadi bias sehingga tidak dapat dijadikan sebagai alat untuk mengevaluasi risiko perusahaan (Haniati dan Fitriany, 2010). Mayangsari dan Wilopo (2002) menyatakan bahwa konservatisme merupakan konsep akuntansi yang kontroversial dan membuktikan bahwa konservatisme akuntansi memiliki relevansi nilai, yang berarti akuntansi bermanfaat dalam memprediksi kondisi keuangan di masa mendatang. Watts (2003) sebagai pendukung konservatisme lainnya berpendapat bahwa konservatisme merupakan salah satu karakteristik yang sangat penting dalam mengurangi biaya agensi dan meningkatkan kualitas informasi laporan keuangan sehingga pada akhirnya akan meningkatkan nilai perusahaan dan harga sahamnya.

- Berdasarkan uraian yang telah dipaparkan diatas, penelitian ini diberi judul: "Pengaruh Konservatisme Akuntansi Terhadap Asimetri Informasi (Studi Empiris Pada Perusahaan Manufaktur di BEI)".

Tujuan penelitian adalah sebagai berikut: Adapun tujuan dari penelitian ini dilakukan adalah untuk mengetahui pengaruh konservatisme akuntansi terhadap asimetri informasi pada laporan tahunan perusahaan manufaktur yang terdaftar di Bursa Efek Indonesia.

\section{Landasan Teori}

\section{Teori Keagenan (Agency Theory)}

Lahirnya Agency theory berawal dari adanya bentuk koorporasi yang memisahkan dengan tegas antara kepemilikan perusahaan dengan kontrol atau dengan kata lain ada pemisahan yang jelas antara pemilik perusahaan dengan pihak manajemen. Semakin rumit dan besarnya suatu perusahaan membuat pihak pemilik tidak bisa secara intensif mengelola perusahaannya, sehingga meminta pihak manajemen untuk mengelola kelangsungan hidup perusahaan dalam usahanya mendapatkan profit. Selanjutnya manajemen dianggap sebagai "agent" dan pemilik dianggap sebagai "principal". Hubungan tersebut oleh banyak ahli disebut dengan hubungan keagenan (agency relationship).

Jensen dan Meckling (2006) tentang agency relationship memberi suatu definisi sebagai berikut: An agency relationship is defined as "a contract under which one or more persons (principal(s)) engage another person (the agent) to perform some service on their behalf which involves delegating some decision making; authority to agent", yang artinya bahwa suatu pendelegasian wewenang telah diberikan oleh pihak pemilik kepada pihak perusahaan dalam bentuk pembuatan keputusan dalam perusahaan. Dalam konteks perusahaan, manajemen bertindak sebagai orang yang diberi amanah oleh pemilik modal (Shareholder dan bondholder). Hubungan tersebut memberi konsekuensi, manajemen yang bertindak atas nama perusahaan dituntut melaksanakan kepentingan principal, dengan kata lain manajemen yang telah diberi otorisasi dalam pengambilan keputusan secara sadar harus bertindak dalam konteks yang memberi keuntungan pada kepentingan principal (Jensen and Meckling, 2006:308).

\section{Asimetri Informasi (Information Assimetry)}

Atiqah (2008:25) menjelaskan asimetri informasi sebagai situasi yang terbentuk karena principal (pemegang saham) tidak memiliki informasi yang cukup mengenai kinerja agen (manajer) sehingga principal tidak pernah dapat menentukan kontribusi usaha-usaha agen terhadap hasil-hasil perusahaan yang sesungguhnya.

Scott (2000) menyatakan bahwa terdapat dua macam langkah asimetri informasi dalam penyampaian informasi baik keuangan maupun non keuangan yaitu:

1) Adverse selection adalah para manajer serta orang dalam lainnya biasanya mengetahui lebih banyak informasi dibandingkan investor sebagai pihak luar. Dan fakta yang mungkin dapat mempengaruhi keputusan yang akan diambil oleh pemegang saham tersebut tidak disampaikan informasinya kepada pemegang saham.

2) Moral hazard adalah kegiatan yang dilakukan oleh seorang manajer tidak 
seluruhnya diketahui oleh pengguna saham ataupun pemberi pinjaman. Sehingga manajer dapat melakukan tindakan diluar pengetahuan pemegang saham yang melanggar kontrak dan sebenarnya secara etika atau norma mungkin tidak layak dilakukan.

Adanya asimetri informasi memungkinkan adanya konflik yang terjadi antara principal dan agent untuk saling mencoba memanfaatkan pihak lain untuk kepentingan sendiri. Eisenhardt (2009) mengemukakan tiga asumsi sifat dasar manusia yaitu: (1) manusia pada umumnya mementingkan diri sendiri (self interest), (2) manusia memiliki daya pikir terbatas mengenai persepsi masa mendatang (bounded rationality), dan (3) manusia selalu menghindari resiko (risk adverse). Berdasarkan asumsi sifat dasar manusia tersebut menyebabkan bahwa informasi yang dihasilkan manusia untuk manusia lain selalu dipertanyakan reliabilitasnya dan dapat dipercaya tidaknya informasi yang disampaikan.

\section{Konservatisme Akuntansi}

Prinsip konservatisme menyatakan bahwa dalam keadaan yang tidak pasti manajer perusahaan akan menentukan pilihan perlakuan atau tindakan akuntansi yang didasarkan pada keadaan, harapan kejadian, atau hasil yang dianggap kurang menguntungkan. Penggunaan prinsip konservatisme dimaksudkan agar pengakuan dan pengukuran aset serta laba dilakukan dengan penuh kehati-hatian. Hal itu disebabkan oleh ketidakpastian yang melingkupi aktivitas ekonomi dan bisnis (Suwardjono, 1989 dalam Dewi, 2004). Tujuan konservatisme untuk menjamin harta, laba dan kekayaan pemilik tidak disajikan terlalu tinggi atau overstated namun karena pentingnya laba sebagai ukuran kemajuan perusahaan maka konsep ini harus diterapkan secara tepat dan teliti dengan memperhitungkan pengaruhnya terhadap proses perhitungan rugi laba tersebut (Ardiyos, 2000:247).

Watts (2002:112) mendefinisikan konservatisme sebagai perbedaan verifiabilitas yang diminta untuk pengakuan laba dibandingkan rugi. Watts juga menyatakan bahwa konservatisme akuntansi muncul dari insentif yang berkaitan dengan biaya kontrak, litigasi, pajak, dan politik yang bermanfaat bagi perusahaan untuk mengurangi biaya keagenan dan mengurangi pembayaran yang berlebihan kepada pihak-pihak seperti manajer, pemegang saham, pengadilan, dan pemerintah. Selain itu, konservatisme juga menyebabkan understatement terhadap laba dalam periode kini yang dapat mengarahkan pada overstatement terhadap laba pada periodeperiode berikutnya, sebagai akibat understatement terhadap biaya pada periode tersebut.

$$
\text { Wolk et al., (2001:144-145) }
$$

memberikan definisi konservatisme akuntansi sebagai usaha untuk memilih metode akuntansi berterima umum yang meliputi sebagai berikut :

1. Memperlambat pengakuan revenues,

2. Mempercepat pengakuan expenses,

3. Merendahkan penilaian aktiva, dan

4. Meninggikan penilaian utang.

Konservatisme akuntansi secara tradisional didefinisikan sebagai antisipasi terhadap semua rugi tetapi tidak mengantisipasi laba (Watts, 2003:241). Menurut Watts (2003:253), mengantisipasi laba berarti mencatat laba sebelum ada klaim secara hukum dihubungkan dengan aliran kas di masa yang akan datang dan sebaliknya tidak mengantisipasi laba berarti belum mencatat laba sebelum ada klaim secara hukum dihubungkan dengan aliran kas di masa yang akan datang, sedangkan pengantisipasian rugi berarti pengakuan rugi sebelum suatu verifikasi secara hukum dapat dilakukan.

Munawir (2004:156) menyatakan bahwa apabila perusahaan memilih suatu diantara dua teknik akuntansi yang ada, maka harus dipilih alternatif yang kurang menguntungkan bagi ekuitas pemegang saham. Teknik yang dipilih adalah teknik yang menghasilkan nilai aset dan pendapatan yang rendah atau yang menghasilkan nilai utang dan biaya yang tinggi. Konsekuensinya, apabila terdapat kondisi yang kemungkinan menimbulkan kerugian, biaya atau utang, maka kerugian, biaya dan utang tersebut harus segera diakui. Sebaliknya, apabila terdapat kondisi yang memungkinkan laba, pendapatan atau aset, maka laba, pendapatan atau aset tidak dapat langsung diakui sampai kondisi tersebut benar-benar telah terjadi. Konservatisme merupakan pandangan yang pesimistik dalam akuntansi. Akuntansi yang 
konservatif berarti bahwa akuntan bersikap pesimis dalam menghadapi ketidakpastian laba atau rugi dengan menggunakan prinsip memperlambat pengakuan pendapatan, mempercepat pengakuan biaya, merendahkan penilaian aset dan meninggikan penilaian utang.

Standar Akuntansi Keuangan (SAK) menyebutkan ada beberapa metode yang menerapkan prinsip konservatisme. Oleh karena itu konservatif merupakan salah satu metode yang dapat digunakan perusahaan dalam melaporkan laporan keuangannya. Hal tersebut akan mengakibatkan angka-angka yang berbeda dalam laporan keuangan yang pada akhirnya akan menyebabkan laba yang cenderung konservatif.

Dalam Ikatan Akuntansi Indonesia (IAI) Standar Akuntansi keuangan (SAK) yang telah mengadopsi Internasional Financial Reporting Standart (IFRS) yang mulai berlaku tanggal 1 Januari 2012 menyebutkan ada beberapa metode yang menerapkan prinsip konservatisme:

1) PSAK No. 14 mengenai persediaan yang terkait dengan pemilihan perhitungan biaya persediaan.

2) PSAK No. 16 mengenai aset tetap dan penyusutan.
3) PSAK No. 19 mengenai aset tidak berwujud yang berkaitan dengan amortisasi.

Literatur terdahulu menyebutkan berbagai cara untuk mengukur tingkat konservatisme. Penman dan Zhang (2002,2000) menggunakan Conservatism Index (C-score) sebagai proksi konservatisme neraca dan Earnings Quality Indicator (Q-score) untuk menghitung tingkat konservatisme laporan laba rugi. $C$ score menunjukkan tingkat estimasi cadangan akibat penggunaan metode akuntansi konservatif. Q-score menunjukkan kualitas laba akibat penggunaan metode yang konservatif.

Ukuran konservatisme lainnya berdasarkan pada observasi bahwa konservatisme menyebabkan kejadiankejadian yang merupakan bad news atau good news terefleksi dalam laba pada waktu yang tidak sama. Hal ini disebabkan karena salah satu definisi konservatisme menyebutkan bahwa kejadian yang diperkirakan akan menyebabkan kerugian bagi perusahaan harus segera diakui sehingga mengakibatkan bad news lebih cepat terefleksi dalam laba dibandingkan good news (Watts, 2001).

Berdasarkan telaah pustaka penelitian, maka kerangka model yang dapat disajikan untuk penelitian ini adalah seperti tertera pada Gambar 2.1.

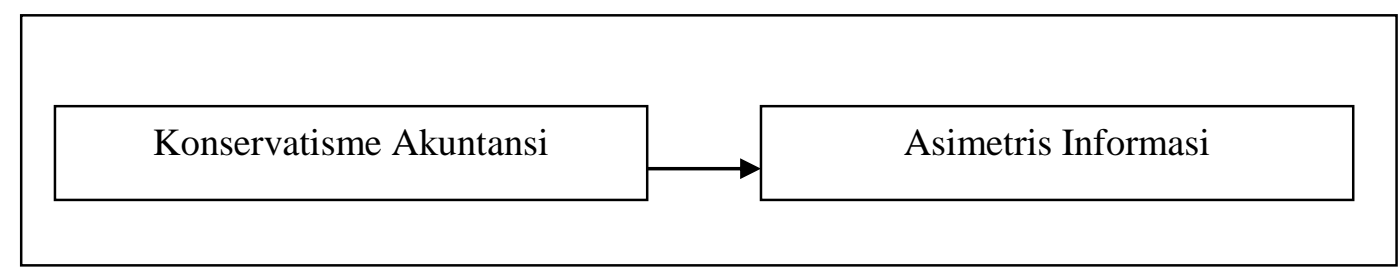

Gambar 2.1 Skema Paradigma Penelitian

Indonesia (BEI) tahun pengamatan 2009-

\section{Hipotesis}

Berdasarkan teori dan kerangka pemikiran, maka hipotesis penelitian ini dapat dirumuskan yaitu konservatisme akuntansi berpengaruh terhadap Asimetri Informasi.

\section{Metode Penelitian \\ Populasi dan Sampel Penelitian}

Populasi adalah keseluruhan objek yang diteliti dan terdiri atas sejumlah individu, baik yang terbatas maupun tidak terbatas (Sumarni dan Wahyuni, 2005: 68). Populasi sasaran adalah populasi spesifik yang relevan dengan tujuan dan masalah penelitian (Teguh, 2005:120). Sampel pada penelitian ini adalah perusahaan manufaktur yang terdaftar di Bursa Efek
2011 dengan menggunakan metode Purposive Random Sampling. Purposive Random Sampling adalah pemilihan sekelompok subjek didasarkan atas ciri-ciri atau sifat-sifat tertentu yang dipandang mempunyai sangkut paut yang erat dengan ciri-ciri atau sifat-sifat populasi yang sudah diketahui sebelumnya (Hadi, 2000). Adapun kriteria-kriteria dalam pengambilan sampel adalah sebagai berikut:

1) Perusahaan manufaktur yang terdaftar di Bursa Efek Indonesia selama periode tahun 2009-2011.

2) Perusahaan tersebut tidak mengalami kerugian selama periode pengamatan.

3) Perusahaan tersebut menyajikan daftar penawaran dan permintaan harga saham. 
Berdasarkan kriteria tersebut, jumlah sampel yang digunakan pada penelitian ini dapat dilihat pada Tabel 3.1

Tabel 3.1

Sampel Penelitian

\begin{tabular}{|l|c|}
\hline \multicolumn{1}{|c|}{ Kriteria Sampel Penelitian } & $\begin{array}{c}\text { Jumlah } \\
\text { Perusahaan }\end{array}$ \\
\hline $\begin{array}{l}\text { Perusahaan manufaktur yang secara berkesinambungan } \\
\text { terdaftar di Bursa Efek Indonesia selama periode 2009- } \\
2011\end{array}$ & $\mathbf{1 6 9}$ \\
\hline $\begin{array}{l}\text { Perusahaan yang mengalami kerugian selama periode } \\
\text { pengamatan }\end{array}$ & $\mathbf{( 8 3 )}$ \\
\hline $\begin{array}{l}\text { Perusahaan yang tidak menyajikan daftar penawaran dan } \\
\text { permintaan harga saham selama periode 2009-2011 }\end{array}$ & $\mathbf{( 6 3 )}$ \\
\hline Jumlah sampel & $\mathbf{2 3}$ \\
\hline Jumlah sampel selama 3 tahun $(23 \times \mathbf{3})$ & 69 \\
\hline
\end{tabular}

Sumber: Data Diolah (2013)

Data yang digunakan dalam penelitian ini adalah data sekunder. Data sekunder adalah data yang diperoleh melalui sumber yang ada (Sekaran, 2006:77). Data sekunder umumnya berupa bukti, catatan atau laporan historis yang telah tersusun dalam arsip (data dokumen yang telah dipublikasikan). Data yang digunakan dalam penelitian berupa laporan keuangan perusahaan dan daftar harga saham penawaran dan permintaan perusahaan manufaktur yang terdaftar di Bursa Efek Indonesia tahun 2009-2011. Data yang digunakan adalah laporan keuangan selama tahun 2009-2011 yang diperoleh dari Pusat Referensi Pasar Modal (PRPM).

\section{Operasionalisasi Variabel}

Ada dua variabel yang digunakan dalam penelitian ini, yaitu variabel dependen/terikat dan variabel independen/bebas. Menurut Sekaran (2006a:116), variabel dependen/terikat merupakan variabel yang menjadi perhatian utama peneliti. Variabel dependen merupakan variabel utama yang menjadi faktor yang berlaku dalam investigasi. Variabel independen/bebas adalah variabel yang mempengaruhi variabel dependen, baik secara positif atau negatif. Pada penelitian ini, yang menjadi variabel dependen adalah asimetri informasi, dan yang menjadi variabel independennya adalah konservatisme akuntansi.

1) Asimetri Informasi
Asimetri informasi adalah suatu keadaan dimana agent mempunyai informasi yang lebih banyak tentang perusahaan dan prospek dimasa yang akan datang dibandingkan dengan principal (Rahmawati dan Triatmoko, 2007). Asimetri informasi diukur dengan menggunakan bid-ask spread. Penggunaan bid-ask spread sebagai proksi dari asimetri informasi menurut Komalasari (2001) dikarenakan dalam mekanisme pasar modal, pelaku pasar modal juga menghadapi masalah keagenan.

$$
\begin{gathered}
\% \text { spread }=(\text { ask price }- \text { bid } \\
\text { price }) /((\text { ask price + bid price }) / 2)
\end{gathered}
$$

Dimana:

ask price = harga ask tertinggi saham perusahaan

$$
\begin{aligned}
& \text { bid price = harga bid terendah saham } \\
& \text { perusahaan }
\end{aligned}
$$

2) Konservatisme Akuntansi

Konservatisme akuntansi adalah antisipasi terhadap semua rugi tetapi tidak mengantisipasi laba (Watts, 2003241) Ukuran yang dapat digunakan untuk mengetahui konservatisme akuntansi adalah net asset measure menggunakan market to book value ratio sebagai proksi pengukuran yang mencerminkan nilai pasar aktiva relatif terhadap nilai buku aktiva perusahaan. Apabila rasio bernilai lebih dari 1 mengindikasikan penerapan akuntansi yang konservatif 
karena perusahaan mencatat nilai perusahaan lebih rendah dari nilai pasarnya, apabila rasio kurang dari 1 mengindikasikan penerapan akuntansi yang optimis karena perusahaan mencatat nilai perusahaan lebih tinggi

$$
\text { Market to Book Value Ratio }=\frac{\text { Harga Pasar Saham Rata }- \text { rata }}{\text { Nilai Buku Saham }}
$$

bawah. Di dalam penelitian ini, pengujian terhadap gejala autokorelasi dilakukan dengan uji "Durbin Watson" (D.W. Test).

\section{Metode Analisis}

Analisa dilakukan dengan menggunakan metode regresi linier sederhana dengan menggunakan paket program SPSS 20.0 (Statistical Program for Social Science). Regresi linier sederhana digunakan untuk menguji variabel independen secara individu. Persamaan adalah sebagai berikut:

$$
Y=\alpha+\beta X+\varepsilon
$$

Dimana:

$$
\begin{aligned}
& Y \text { : Asimetri Informasi } \\
& \alpha \text { : Konstanta } \\
& \beta \text { : Koefisien Regresi } \\
& X \text { : Konservatisme Akuntansi } \\
& \varepsilon \text { : Error term }
\end{aligned}
$$

Sebelum data dianalisis terlebih dahulu akan dilakukan pengujian terhadap data yang dilakukan dengan uji asumsi klasik

\section{Uji Asumsi Klasik Uji Normalitas}

Pengujian normalitas digunakan untuk mengetahui apakah distribusi data penelitian masing-masing variabel telah menyebar secara normal atau tidak, hal ini dapat dilakukan dengan melihat sebaran standarized pada kurva $P-P$ plots, bila standarized residual berada pada kisaran garis normal maka data mempunyai distribusi normal (Santoso, 2000 : 258).

\section{Uji Autokorelasi}

Uji autokorelasi yaitu terdapatnya korelasi serial diantara kesalahan (error terms) dari serangkaian observasi yang disusun dalam runtun waktu (time series data) atau data silang (cross section), adanya gejala autokorelasi dalam model akan mengakibatkan taksiran tidak efisien dan varian dari taksiran akan bias ke regresi yang digunakan dalam penelitian ini dari nilai pasarnya. Adapun market to book value dihitung dengan persamaan sebagai berikut (Hariyanto dan Sudono, 1998): Auto Korelasi adalah jika DW $>$ DU atau $\mathrm{DW}<4-$ du maka tidak ada serial Autokorelasi baik positif maupun negatif (Gujarati, 2001 :167).

\section{Uji Heterokedastisitas}

Uji heterokedastisitas dilakukan untuk mengetahui apakah dalam sebuah model regresi terjadi ketidaksamaan variance dari residual suatu pengamatan ke pengamatan lain. Jika variasi dari residual suatu pengamatan ke pengamatan lain tetap disebut homokedastisitas, sementara untuk variasi yang berbeda disebut heterokedastisitas. Model regresi yang baik adalah tidak terjadi heterokedastisitas (Husein, 2007:179). Untuk mendeteksi ada tidaknya heterokedastisitas dapat dilihat dari uji Glejser yang dilakukan dengan membuat model regresi yang melibatkan nilai mutlak residu sebagai variabel terikat terhadap semua variabel (Ghozali, 2006). Jika variasi residu tidak sama untuk semua pengamatan maka terjadi heterokedastisitas.

Uji $\mathbf{t}$

Uji t ini dilakukan untuk melihat pengaruh variable-variabel independen terhadap variabel dependen secara individu (parsial). Dengan menganggap variable lainnya konstan. Bila t-hit $>$ t-tabel dengan nilai signifikan dibawah 5\%, maka dapat disimpulkan bahwa secara parsial variable independen berpengaruh signifikan terhadap variabel dependen. Jika $\mathrm{t}$-hit $<\mathrm{t}$-tabel dengan nilai signifikan diatas $5 \%$ maka dapat disimpulkan variabel independen tidak berpengaruh terhadap variabel dependen.

\section{Analisis Data Dan Pembahasan Deskripsi Responden}

Deskripsi data memberikan
gambaran mengenai karakteristik
responden penelitian yang diamati.
Deskripsi responden yang digunakan


dalam penelitian dapat dilihat pada Tabel 4.1 berikut :

Tabel 4.1

Data Responden Tahun 2009-2011

\begin{tabular}{|c|c|c|}
\hline No. & Nama Perusahaan & Jenis Usaha \\
\hline 1 & Adhi Karya Tbk & Industri Pembangunan Perumahan \\
\hline 2 & Ades Afindo Tbk & Industri Makanan dan Minuman \\
\hline 3 & Astra Graphia Tbk & Industri Dagang Umum \\
\hline 4 & BAT Indonesia Tbk & Industri Rokok (Tembakau) \\
\hline 5 & Branta Mulia Tbk & Industri Ban \\
\hline 6 & Barito Pacific Tbk & Industri Kayu \\
\hline 7 & Budi Acid Jaya Tbk & Industri Makanan dan Minuman \\
\hline 8 & Gudang Garam Tbk & Industri Rokok (Tembakau) \\
\hline 9 & Kabelindo Murni Tbk & Industri Alat Listrik \\
\hline 10 & Kalbe Farma Tbk & Industri Obat-obatan \\
\hline 11 & Sari Husada Tbk & Industri Makanan dan Minuman \\
\hline 12 & SMART Tbk & Industri Makanan dan Minuman \\
\hline 13 & Semen Cibinong Tbk & Industri Semen \\
\hline 14 & Semen Gresik Tbk & Industri Semen \\
\hline 15 & Siantar TOP Tbk & Industri Makanan dan Minuman \\
\hline 16 & $\begin{array}{l}\text { Tunas Baru Lampung } \\
\text { Tbk }\end{array}$ & Industri Makanan dan Minuman \\
\hline 17 & Tembaga Mulia Tbk & Industri Alat Listrik \\
\hline 18 & Mandom Indonesia Tbk & Industri Kosmetik \\
\hline 19 & Tirta Mahakam Tbk & Industri Kayu \\
\hline No. & Nama Perusahaan & Jenis Usaha \\
\hline 20 & Surya Toto Tbk & Industri Produk Kebersihan dan Dapur \\
\hline 21 & United Tractors Tbk & Industri Alat Berat \\
\hline 22 & Unilever Indonesia Tbk & Industri Makanan dan Minuman \\
\hline 23 & Voksel Electric Tbk & Industri Alat Listrik \\
\hline
\end{tabular}

Sumber: Data Diolah (2013)

\section{Analisis Konservatisme Akuntansi}

Ukuran yang dapat digunakan untuk mengetahui konservatisme akuntansi adalah net asset measure menggunakan market to book value ratio sebagai proksi pengukuran yang mencerminkan nilai pasar aktiva relatif terthadap nilai buku aktiva perusahaan. Apabila rasio bernilai lebih dari 1 mengindikasikan penerapan akuntansi yang konservatif karena perusahaan mencatat nilai perusahaan lebih rendah dari nilai pasarnya, apabila rasio kurang dari 1 mengindikasikan penerapan akuntansi yang optimis karena perusahaan mencatat nilai perusahaan lebih tinggi dari nilai pasarnya. Pengukuran ini dilakukan dengan cara membagi harga pasar saham rata-rata dengan nilai buku saham. Pengukuran menggunakan market to book value ratio dapat dilihat dalam lampiran 1-3.

Untuk mengetahui perkembangan konservatisme akuntansi pada perusahaan Manufaktur di Bursa Efek Indonesia dapat dilihat pada Tabel 4.2 
Tabel 4.2

Konservatisme Akuntansi pada Perusahaan Manufaktur di BEI

Tahun 2009-2011

\begin{tabular}{|l|c|c|c|}
\hline & $\mathbf{2 0 0 9}$ & $\mathbf{2 0 1 0}$ & $\mathbf{2 0 1 1}$ \\
\hline 1. Adi Karya Tbk & 3,038 & 3,110 & 2,736 \\
2. Ades Afindo Tbk & 1,785 & 1,643 & 1,577 \\
3. Astra Graphia Tbk & 1,696 & 1,750 & 1,897 \\
4. BAT Indonesia Tbk & 1,771 & 1,619 & 1,661 \\
5. Branta Mulia Tbk & 1,740 & 1,774 & 1,586 \\
6. Barito Pacific Tbk & 2,545 & 2,458 & 2,992 \\
7. Budi Acid Jaya Tbk & 2,730 & 2,698 & 2,146 \\
8. Gudang Garam Tbk & 1,701 & 1,624 & 1,552 \\
9. Kabelindo Murni Tbk & 1,502 & 1,532 & 1,989 \\
10. Kalbe Farma Tbk & 1,679 & 1,765 & 1,738 \\
11. Sari Husada Tbk & 1,575 & 1,451 & 1,528 \\
12. SMART Tbk & 1,566 & 1,462 & 1,373 \\
13. Semen Cibinong Tbk & 1,505 & 1,813 & 1,429 \\
14. Semen Gresik Tbk & 6,354 & 9,109 & 8,352 \\
15. Siantar TOP Tbk & 1,532 & 1,606 & 1,571 \\
16. Tunas Baru Lampung & 1,519 & 1,643 & 1,524 \\
Tbk & 1,465 & 1,568 & 1,615 \\
17. Tembaga Mulia Tbk & 1,641 & 1,592 & 1,861 \\
18. Mandom Indonesia Tbk & 3,556 & 1,884 & 1,437 \\
19. Tirta Mahakam Tbk & 2,579 & 2,696 & 2,545 \\
20. Surya Toto Tbk & 2,446 & 2,605 & 2,315 \\
21. United Tractors Tbk & 1,683 & 1,956 & 1,733 \\
22. Unilever Indonesia Tbk & 1,616 & 1,662 & 1,807 \\
23. Voksel Electric Tbk & & & \\
\hline
\end{tabular}

Sumber : Bursa Efek Indonesia 2013, (Diolah)

Dari Tabel 4.2 menunjukkan bahwa konservatisme akuntansi yang dilakukan terhadap 23 perusahaan yang menjadi populasi penelitian. Berdasarkan hasil tersebut maka dapat disimpulkan bahwa 23 perusahaan dapat digolongkan sebagai perusahaan yang konservatif. Konservatisme akuntansi yang diukur dengan menggunakan proksi pengukuran market to book value ratio dari tahun 20092011 mengalami perkembangan yang relatif baik dimana dari jumlah populasi sebanyak 23 perusahaan memiliki nilai market to book value ratio lebih besar dari satu. Tabel 4.2 terlihat bahwa Semen Gresik Tbk mempunyai angka konservatisme yang terbesar bahkan di atas rata-rata perusahaan lainnya. Hal ini memberikan fenomena bahwa perbandingan harga saham pada perusahaan Semen Gresik Tbk terhadap nilai buku saham lebih besar sehingga diperoleh konservatisme yang besar. Nilai konservatis terkecil terlihat pada SMART Tbk terutama pada Tahun 2010, salah satu penyebab hal tersebut di sinyalir oleh kebijakan manajer yang memberi batasan pada strategi konservatif pada perusahaan.

\section{Analisis Asimetri Informasi}

Untuk mengetahui bagaimana perkembangan asimetri informasi yaitu suatu keadaan dimana agent mempunyai informasi yang lebih banyak tentang perusahaan dan prospek dimasa yang akan datang dibandingkan dengan principal pada perusahaan Manufaktur di Bursa Efek Indonesia. Pengukuran asimetri informasi dengan metode bid ask spread yang mana perhitungannya dapat dilihat pada lampiran 4-6. Hasil dari pengukuran asimetri informasi tersebut dapat dilihat pada Tabel 4.3. 
Tabel 4.3

Asimetri Informasi pada Perusahaan Manufaktur di BEI Tahun 2009-2011

\begin{tabular}{|l|l|l|l|}
\hline & $\mathbf{2 0 0 9}$ & $\mathbf{2 0 1 0}$ & $\mathbf{2 0 1 1}$ \\
\hline 1. Adi Karya Tbk & 0,08 & 0,03 & 0,14 \\
2. Ades Afindo Tbk & 0,05 & 0,01 & 0,03 \\
3. Astra Graphia Tbk & 0,10 & 0,01 & 0,09 \\
4. BAT Indonesia Tbk & 0,07 & 0,03 & 0,03 \\
5. Branta Mulia Tbk & 0,11 & 0,03 & 0,06 \\
6. Barito Pacific Tbk & 0,05 & 0,03 & 0,03 \\
7. Budi Acid Jaya Tbk & 0,05 & 0,01 & 0,11 \\
8. Gudang Garam Tbk & 0,04 & 0,00 & 0,03 \\
9. Kabelindo Murni Tbk & 0,09 & 0,02 & 0,11 \\
10. Kalbe Farma Tbk & 0,07 & 0,02 & 0,04 \\
11. Sari Husada Tbk & 0,05 & 0,05 & 0,07 \\
12. SMART Tbk & 0,03 & 0,13 & 0,09 \\
13. Semen Cibinong Tbk & 0,03 & 0,02 & 0,08 \\
14. Semen Gresik Tbk & 0,04 & 0,05 & 0,03 \\
15. Siantar TOP Tbk & 0,05 & 0,02 & 0,02 \\
16. Tunas Baru Lampung Tbk & 0,08 & 0,02 & 0,03 \\
17. Tembaga Mulia Tbk & 0,02 & 0,02 & 0,11 \\
18. Mandom Indonesia Tbk & 0,03 & 0,05 & 0,03 \\
19. Tirta Mahakam Tbk & 0,05 & 0,05 & 0,10 \\
20. Surya Toto Tbk & 0,05 & 0,16 & 0,06 \\
21. United Tractors Tbk & 0,03 & 0,07 & 0,07 \\
22. Unilever Indonesia Tbk & 0,04 & 0,05 & 0,05 \\
23. Voksel Electric Tbk & 0,17 & 0,12 & 0,03 \\
\hline
\end{tabular}

Sumber : Bursa Efek Indonesia 2013, (Diolah)

Dari Tabel 4.3 memperlihatkan bahwa hasil pengukuran asimetri informasi dari 23 perusahaan yang konservatif tersebut memiliki rata-rata nilai asimetri informasi yang positif. Perusahaan Surya Toto Tbk mempunyai nilai asimetri informasi tertinggi di antara perusahaan yang lain, perusahaan yang kegiatan usahanya adalah memproduksi produk sanitary, fittings, dan kitchen systems ini mencatat nilai laba yang tinggi pada tahun 2010 dan hal ini ditandai dengan banyaknya aktifitas investor yang membeli saham perusahaan tersebut. Sedangkan perusahaan Gudang Garam Tbk yang kegiatan usahanya memproduksi produk rokok ini memiliki nilai asimetri informasi terendah pada tahun 2010, hal ini ditandai dengan harga bid dan ask saham yang berada pada nilai yang normal sehingga

tidak terlihat pembelian saham yang mencolok dari investor. Dari hal tersebut dapat disimpulkan bahwa pasar memiliki response yang positif terhadap perusahaan yang asimetri, atau dengan kata lain dapat disimpulkan bahwa pasar lebih cepat bereaksi terhadap laba yang diumumkan oleh perusahaan asimetri yang mengindikasikan investor cenderung lebih optimis.

\section{Hasil Uji Asumsi Klasik Hasil Uji Normalitas}

Dari hasil penelitian diperoleh sebaran standarized pada kurva $P$ - $P$ plots, berada pada kisaran garis normal maka dapat disimpulkan bahwa data terdistribusi secara normal, seperti ditunjukkan pada Gambar 4.1. 


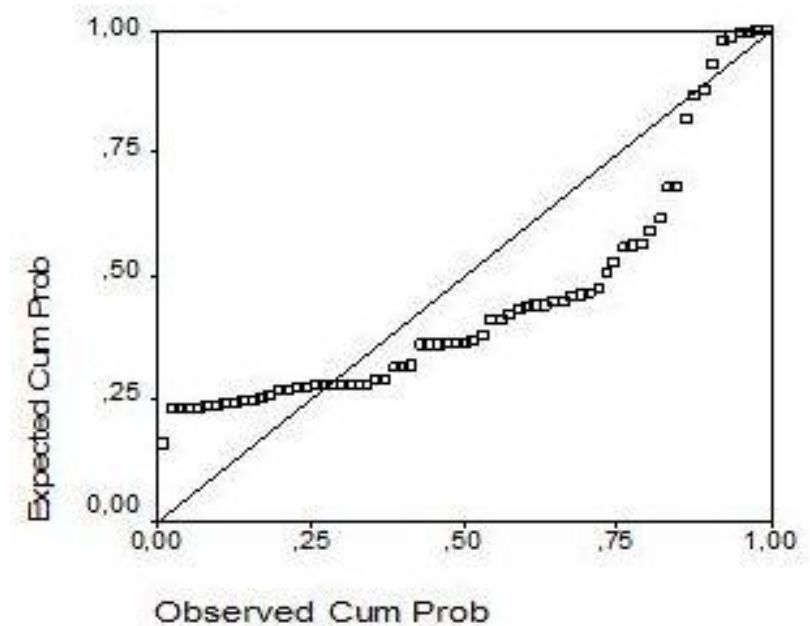

Gambar 4.1 Normal P-P Plot of Regression Standardized

\section{Hasil Uji Autokorelasi}

Untuk mengetahui apakah Autokorelasi terdapat dalam kejadian tertentu adalah dengan menggunakan tes Durbin Watson. Dasar pengambilan keputusan dalam uji Auto Korelasi adalah jika $\mathrm{DU}<\mathrm{DW}<4$-du maka tidak ada serial Autokorelasi baik positif maupun negatif. Hasil penelitian menunjukkan nilai DW sebesar 2,095 lebih besar dari DU yaitu 1,604 maka dapat disimpulkan tidak terdapat autokorelasi dari variabel-variabel yang ada dalam penelitian ini.

\section{Hasil Uji Heteroskedastisitas}

Berdasarkan hasil pengujian heteroskedastisitas menunjukkan bahwa variabel bebas dalam penelitian dibawah nilai probabilitas 0,05 . Maka dapat disimpulkan bahwa tidak terjadi heteroskedastisitas dalam penelitian ini.

\section{Hasil Pengujian Hipotesis}

Untuk mengetahui pengaruh konservatisme akuntansi terhadap asimetri informasi pada laporan tahunan perusahaan manufaktur yang terdaftar di Bursa Efek Indonesia maka akan dilakukan pengujian dengan menggunakan alat ukur regresi linear sederhana. Regresi linear yang dihasilkan menggunakan program SPSS (Statistical Program for Social Science) versi 20.0 dapat dilihat pada lampiran 7. Hasil penelitiannya dapat dilihat pada Tabel 4.4.

Tabel 4.4

Hasil Perhitungan Regresi

\begin{tabular}{|c|c|c|}
\hline \multicolumn{3}{|c|}{$\begin{array}{l}\text { Persamaan Regresi linear Sederhana } \\
\qquad Y=0,0829-0,474 X\end{array}$} \\
\hline Variabel & B & $\begin{array}{l}\text { Standar } \\
\text { Error }\end{array}$ \\
\hline $\begin{array}{l}\text { (Constant) } \\
\text { Konservatisme akuntansi }\end{array}$ & $\begin{array}{l}0,0829 \\
-0,474\end{array}$ & $\begin{array}{l}0,016 \\
0,082\end{array}$ \\
\hline $\begin{array}{ll}R \text {-square } & =0,240 \\
\text { R-korelasi } & =0,490\end{array}$ & & \\
\hline
\end{tabular}

Sumber: Hasil Pengolahan Data (2013)

Berdasarkan hasil penelitian diperoleh persamaan akhir estimator yaitu: $Y=0,0829-0,474 X$. Persamaan tersebut mengandung pengertian bahwa konstanta sebesar 0,0829 artinya apabila variabel konservatisme akuntansi dianggap konstan maka asimetri informasi pada laporan tahunan perusahaan manufaktur yang terdaftar di Bursa Efek Indonesia hanya sebesar 0,0829 persen.

Dari hasil penelitian diperoleh nilai koefisien regresi konservatisme akuntansi sebesar -0,474 artinya apabila konservatisme akuntansi mengalami perubahan yang meningkat sebesar 1 persen maka akan berpengaruh terhadap menurunnya tingkat asimetri informasi pada laporan tahunan perusahaan manufaktur yang terdaftar di Bursa Efek Indonesia sebesar 0,474 persen dengan asumsi variabel lain selain konservatisme akuntansi yang mempengaruhi asimetri informasi dianggap tetap, atau apabila konservatisme akuntansi mengalami perubahan yang menurun sebesar 1 persen 
maka akan berpengaruh terhadap meningkatnya tingkat asimetri informasi pada laporan tahunan perusahaan manufaktur yang terdaftar di Bursa Efek Indonesia sebesar 0,474 persen dengan asumsi variabel lain selain konservatisme akuntansi yang mempengaruhi asimetri informasi dianggap tetap.

Koefisien korelasi $(R)$ sebesar 0,490 yang menggambarkan bahwa konservatisme akuntansi sangat erat hubungannya terhadap asimetri informasi pada laporan tahunan perusahaan manufaktur yang terdaftar di Bursa Efek Indonesia yaitu sebesar 49,0 persen. Koefisien determinan $\left(R^{2}\right)$ bernilai 0,240 menunjukkan bahwa konservatisme akuntansi mampu mempengaruhi asimetri informasi pada laporan tahunan perusahaan manufaktur yang terdaftar di Bursa Efek Indonesia sebesar 24,0 persen dan sisanya sebesar 76,0 persen di pengaruhi oleh variabel lainnya diluar model penelitian ini seperti struktur kepemilikan manajerial, struktur kepemilikan institusional, struktur kepemilikan publik, ukuran perusahaan, lavarage dan lain-lain.

\section{Pembuktian Hipotesis}

Untuk menguji hipotesis dalam penelitian ini penulis menggunakan uji $\mathrm{t}$ yaitu pada tingkat keyakinan (convidend interval $95 \%$ ) atau tingkat kesalahannya (alpha) $\alpha$ sebesar 0,05. Uji t dilakukan untuk melihat bagaimana pengaruh variabel penjelas terhadap variabel terikat secara parsial.

\section{Uji t-tes}

Untuk variabel kemudahan penggunaan diperoleh t-hit sebesar 5,739 lebih besar dari t-tabel sebesar 1,9960, artinya secara parsial variabel konservatisme akuntansi berpengaruh signifikan dan negatif terhadap asimetri informasi pada laporan tahunan perusahaan manufaktur yang terdaftar di Bursa Efek Indonesia. Mengacu pada syarat tersebut hasil penelitian ini menolak Ho dan menerima Ha.

\section{Kesimpulan Dan Saran}

\section{Kesimpulan}

Berdasarkan pembahasan hasil penelitian yang telah dikemukakan sebelumnya, dapat disimpulkan bahwa:
1) Dari hasil pengukuran konservatisme akuntansi yang dilakukan terhadap 23 perusahaan yang menjadi populasi maka diperoleh hasil semua perusahaan yang memenuhi lebih dari satu asumsi pengukuran konservatisme akuntansi dengan nilai market to book value ratio yang lebih besar dari 1 , sehingga perusahaan tersebut dapat digolongkan sebagai perusahaan yang konservatif.

2) Dari hasil pengujian regresi dapat disimpulkan bahwa koefisien determinan $\left(R^{2}\right)$ bernilai 0,240 menunjukkan bahwa konservatisme akuntansi mampu mempengaruhi asimetri informasi pada laporan tahunan perusahaan manufaktur yang terdaftar di Bursa Efek Indonesia sebesar 24,0 persen dan sisanya sebesar 76,0 persen di pengaruhi oleh variabel lainnya diluar model penelitian ini.

3) Pembuktian yang dilakukan secara parsial menunjukkan bahwa variabel konservatisme akuntansi diperoleh koefisien regresi sebesar $-0,474,(\beta \neq$ $0)$, artinya secara parsial variabel konservatisme akuntansi berpengaruh negatif dan signifikan terhadap asimetri informasi pada laporan tahunan perusahaan manufaktur yang terdaftar di Bursa Efek Indonesia. Mengacu pada syarat tersebut hasil penelitian menolak $\mathrm{Ho}$ dan menerima $\mathrm{Ha}$.

\section{Saran}

Peneliti menyadari sepenuhnya, bahwa masih banyak keterbatasan dalam penelitian ini, antara lain:

1) Penelitian ini hanya meneliti pada perusahaan manufaktur yang terdaftar di Bursa Efek indonesia, sehingga hasilnya tidak dapat digeneralisasikan untuk seluruh perusahaan yang terdaftar di Bursa Efek Indonesia.

2) Pemilihan faktor yang diduga dapat mempengaruhi asimetri informasi hanya dilihat dari satu variabel saja, yaitu konservatisme akuntansi. Hal ini memungkinkan terabaikannya faktorfaktor lain yang mungkin mempunyai pengaruh lebih besar terhadap asimetri informasi.

Untuk menelaah referensi penelitian selanjutnya, ada beberapa saran yang dapat dikemukakan, antara lain: 


\section{Saran Akademis}

1. Berhubung penelitian ini hanya dilakukan pada perusahaan manufaktur saja, untuk penelitian selanjutnya diharapkan dapat memperluas subjek penelitian, tidak hanya pada perusahaan manufaktur, namun juga pada perusahaan seperti industri jasa, industri properti dan industri keuangan, agar populasi yang diambil lebih representatif dan hasil penelitiannya dapat digeneralisasikan untuk semua jenis industri.

2. Diharapkan pada penelitian selanjutnya untuk mengembangkan lagi faktorfaktor lain yang dapat mempengaruhi konservatisme akuntansi karena variabel dalam penelitian ini hanya mampu menjelaskan 24\% variabel konservatisme akuntansi, sedangkan sisanya $76 \%$ dijelaskan oleh variabel lain yang tidak dimasukkan dalam model penelitian ini seperti struktur manajerial, struktur kepemilikan institusional, struktur kepemilikkan publik, ukuran perusahaan, leverage dan lain-lain.

\section{Saran Praktis}

1. Bagi pihak manajemen dan pemilik perusahaan harus mempertimbangkan dengan tepat mengenai variabelvariabel yang mempengaruhinya, agar perusahaan dapat melaporkan keuangannya dengan hati-hati.

2. Bagi investor hendaknya sebelum menanamkan modalnya pada perusahaan, terlebih dahulu memperhatikan laporan keuangan yang diterbitkan perusahaan agar tidak salah mengambil keputusan investasi.

\section{Daftar Pustaka}

Ahmed, Peter dan Robert. H. 2000. Accounting Conservatism \& Cost of Debt: An Empirical Test of Efficient Contracting. SRRN Working Paper. Melalui $<$ http://papers.ssrn.com> [23/11/12]

Ardiyos. 2000. Kamus Besar Akuntansi. Jakarta: Citra Harta Prima.

Atiqah. 2008. Corporate Governance, Pengungkapan Sukarela, dan Asimetri Informasi. Jakarta:
Fakultas Ekonomi Universitas Indonesia.

Eisenhardt, Kathleem. M. 2009. Agency Theory: An Assesment and Review. Academy of management Review Vol. 14, 57-74. Melalui <http://papers.ssrn.com> [23/11/12]

Givoly, D., dan Hayn, C. 2000. The Changing Time-Series Properties of Earnings, Cash Flows and Accruals: Has Financial Reporting Become Conservative?. Journal of Accounting and Economics Vol. 29, 287-320. Melalui $<$ http://journalofaccountancy.com/ $>$ [05/02/2013]

Haniati, Sri., dan Fitriany. 2010. Pengaruh Konservatisme terhadap Asimetri Informasi dengan Menggunakan Beberapa Model Pengukuran Konservatisme, Simposium Nasional Akuntansi 3 Purwokerto. Melalui

<http://www.docstoc.com/docs/92 964652/AKPM_41> [18/11/12]

Jensen, M. C. dan W. H. Meckling. 2006. Theory of the Firm: Managerial Behavior, Agency Cost, and Ownership Structure. Journal of Financial Economics Vol.3, 305$360 . \quad$ Melalui $<\mathrm{http}: / /$ journalofaccountancy.com/ $>$ [05/02/2013]

Komalasari. 2001. Asimetri Informasi dan Cost of Equity Capital. Jurnal Riset Akuntansi Indonesia. Vol.4, No. 1 (Januari) Hal 64-8. Melalui < http://akuntansia.com/> [08/12/12]

Mayangsari, Sekar dan Wilopo. 2002. Konservatisma Akuntansi, Value Relevance dan Discretionary Accruals: Implikasi Empiris Model Feltham-Ohlson (1996). Jurnal Riset Akuntansi Indonesia Vol.3, 291-310. Melalui < http://akuntansia.com/> [08/12/12]
Munawir. 2004. Analisa Laporan Keuangan. Edisi Keempat. Yogyakarta: Liberty.

Penman, S. H., dan X. J. Zhang. 2002. Accounting Conservatism: The 
Quality of Earnings and Stock Returns. The Accounting Review 2: 237-264. Melalui < http://www.sciencedirect.com> [21/02/13]

Rahmawati dan Triatmoko. 2007. Analisis Faktor-Faktor yang Memengaruhi Kualitas Laba dan Nilai Perusahaan. Simposium Nasional Akuntansi $X$. Makassar. Melalui < http://akuntansia.com/> [08/12/12]

Scott, W.R. 2000. Financial Accounting Theory. New Jersey: Prentice-Hall Inc. Melalui <http://ssrn.com> [07/01/13]

Suwardjono. 2010. Teori Akuntansi Perekayasaan Pelaporan Keuangan. Edisi Ketiga. Yogyakarta: BPFE.

Sekaran, Uma. 2006. Research Methods for Business: Metodologi Penelitian untuk Bisnis. Buku 2. Edisi 4. Terjemahan Kwan Men Yon. Jakarta: Salemba Empat.

Teguh, Muhammad. 2005. Metodologi Penelitian Ekonomi Teori dan Aplikasi. Edisi 1. Jakarta: PT Raja Grafindo Persada.

Watts, R. L. 2002. Conservatism in Accounting. Working Paper, University of Rochester. Melalui < $\mathrm{http}: / / \mathrm{www}$. sciencedirect.com> [21/02/13]

2003. Conservatism in Accounting Part I: Explanations and Implications, Journal of Accounting and Economics. 207221. Melalui < http://www.sciencedirect.com> [21/02/13]

Wolk, Harry I., Michael G. Tearney, dan James L. Dodd. 2001. Accounting Theory: A Conceptual and Institutional Approach, Cincinnati, Ohio: South-Westrn College Publishing. Melalui $<w w w . f c g i . o r . i d>[15 / 01 / 13]$ 